\author{
I.M. Trofymchuk, N.V. Roik, L.A. Belyakova
}

\title{
$\beta$-CYCLODEXTRIN-MCM-41 SILICA AS PROMISING ADSORBENT FOR THE TRACE AMOUNTS REMOVAL OF AROMATICS FROM WATER
}

\author{
Chuiko Institute of Surface Chemistry of National Academy of Sciences of Ukraine \\ 17 General Naumov Str., Kyiv, 03164,Ukraine, E-mail: trofymchuk_iryna@ukr.net
}

\begin{abstract}
Aromatic compounds are organic contaminants in aqueous streams of various industries. Even at low concentration, benzene and its derivatives are toxic agents. Silicas are promising materials for benzene and phenol adsorption from water mixtures due to their unique physical and chemical properties. In this research, we realized sol-gel synthesis of $\beta$-cyclodextrin-MCM-41 silica using $\beta$-cyclodextrin-containing silane and tetraethyl orthosilicate as silica sources in the presence of ionic template (cetyltrimethylammonium bromide). $\beta$-Cyclodextrin-silane was prepared by modification of (3-aminopropyl)triethoxysilane with oligosaccharide activated by $N, N^{\prime}$-carbonyldiimidazole. The successful incorporation of $\beta$-cyclodextrin moieties in silica is verified by means of FT-IR spectroscopy and quantitative chemical analysis. Obtained $\beta$-cyclodextrin-MCM-41 silica was characterized by X-ray diffraction, transmission electron microscopy, and low-temperature adsorption-desorption of nitrogen. On the basis of analysis, $\beta$-cyclodextrin-MCM-41 silica is wellordered mesoporous material with high surface area (about $800 \mathrm{~m}^{2} \cdot \mathrm{g}^{-1}$ ) and sufficient oligosaccharide group loading (up to $\left.0.022 \mu \mathrm{mol} \cdot \mathrm{m}^{-2}\right)$. Adsorption of benzene and phenol from aqueous solutions on $\beta$-cyclodextrin-MCM-41 silica was studied as the function of time and equilibrium concentration. Greater specificity of aromatic compounds adsorption for $\beta$ cyclodextrin-MCM-41 silica in comparison with MCM-41 was demonstrated. Moreover, the higher adsorption performance of $\beta$-cyclodextrin-MCM-41 silica towards benzene and their adsorptive affinity to phenol can be useful in the separation of aromatic compounds. The proposed synthesis approach may be applicable for obtaining of ordered $\beta$-cyclodextrin-containing functional materials with high affinity to aromatic compounds of suitable geometry for water treatment.
\end{abstract}

Keywords: MCM-41, $\beta$-cyclodextrin, sol-gel synthesis, adsorption, aromatic compounds

\section{INTRODUCTION}

Aromatic compounds are organic contaminants in aqueous streams of various industries from production of resin and plastic, leather, paper, synthetic dyes, solvents, pesticides as well as coal conversion and petroleum refining [1]. The widespread using of these chemicals in industry processes also can lead to the presence of aromatic compounds in aquatic environment and drinking water since they exhibit high volatility and spreading as well as low biodegradability. Even at low concentration, benzene and its derivatives are flammable, toxic, carcinogenic, and/or mutagenic agents $[2,3]$. There are a variety of chemical and physical methods that have been suggested for the purification of wastewaters from aromatics. Among them the common used are adsorption [4-15], bio- and photodegradation $[16,17]$, solvent/surfactant extraction [18, 19], chemical oxidation [20], membrane treatment [21], and coagulation-floculation [22]. However, adsorption has been shown to be one of the most effective procedures in the elimination of benzene and its derivatives from aqueous solutions. A number of adsorbents were used for benzene and phenol adsorption from water mixtures, such as activated carbons [4-6], zeolites [7, 8], ceramic and polymeric materials [9-13], and bioadsorbents $[14,15]$. Even taking into account the advantages of these adsorbents, their potential application is often limited by the cost of material, the low efficiency at trace concentration of analytes, and the necessity of sorbent regeneration at high temperatures. So, many efforts have been directed to develop new adsorbents, and silicas are promising materials due to their unique physical and chemical properties as well as possibility of low-cost regeneration.

MCM-41 silicas are ordered mesoporous materials with well-defined uniform pores, high surface area and pore volume. The presence of highly reactive silanol groups on silica surface opens up the possibility for introduction of various organic functional moieties into the surface layer of MCM-41. Among a large number of organic compounds appropriate for silica functionalization, cyclodextrin macromolecules are very promising 
because of their capability to form inclusion complexes with chemicals of suitable geometry and functionality [23].

Here, $\beta$-cyclodextrin-MCM-41 silica was synthesized and tested as adsorbent for aromatic compounds removal from water. Equilibrium and kinetic multibatch adsorption experiments were carried out to elucidate benzene and phenol from aqueous solutions. The sorption properties of $\beta$-cyclodextrin-MCM-41 silica were compared with those of MCM-41 and aminopropylcontaining MCM-41 silicas to estimate the role of oligosaccharide groups in the process of aromatic compound removal from water.

\section{EXPERIMENTAL}

$\beta$-Cyclodextrin hydrate ( $\beta$-CD) $(99 \%$, Acros Organics), tetraethyl orthosilicate (TEOS) ( $\geq 99 \%$, Merck), (3-aminopropyl)triethoxysilane (APTES) ( $\geq 99 \%$, Merck), N,N'-carbonyldiimidazole (CDI) $(\geq 98 \%$, Merck), cetyltrimethylammonium bromide (CTMABr) ( $\geq 97 \%$, Merck), benzene (pure analytical, Reakhim), and phenol (GR for analysis, Lachner) were used as purchased, and no further purification was performed. Aqueous ammonia $25 \%$, ethanol $96 \%$, and hydrochloric acid $37 \%$ were purchased from Reakhim (all analytical grade) and used without additional purification. Acetone (extra pure, Merck) and $\mathrm{N}, \mathrm{N}^{\prime}$-dimethylformamide (DMF) (pure analytical, Reakhim) were dried for $48 \mathrm{~h}$ before utilization with activated molecular sieves $(0.3 \mathrm{~nm}$, Merck).

Synthesis of MCM-41-type silicas. Hexagonally ordered MCM-41 and aminopropylcontaining MCM-41 ( $\left.\mathrm{NH}_{2}-\mathrm{MCM}-41\right)$ silicas were prepared by hydrothermal sol-gel synthesis in the presence of ionic surfactant compound, CTMABr, by the procedure described in [24]. TEOS or TEOS/APTES mixture was used as silica source. The final molar composition of the reaction mixture for $\mathrm{MCM}-41$ and $\mathrm{NH}_{2}-\mathrm{MCM}-41$ silicas preparing by template method was as follows: 0.1 TEOS (or 0.09 TEOS : 0.006 APTES) : 0.02 CTMABr : $0.55 \mathrm{NH}_{4} \mathrm{OH}: 0.56 \mathrm{C}_{2} \mathrm{H}_{5} \mathrm{OH}: 14.4 \mathrm{H}_{2} \mathrm{O}$. Obtained silicas were washed with water and dried at ambient temperature. Then, the template was removed by extraction in acid-ethanol solution.

The co-condensation method was also employed to introduce $\beta$-CD moieties in silica matrix. First, $\beta-C D$ was activated with $\mathrm{CDI}$ to form amide bond [25]. To obtain activated oligosaccharide $(\boldsymbol{I})$, a solution of CDI in dry DMF was added to a solution of anhydrous $\beta-\mathrm{CD}$ in dry
DMF (molar ratio $\mathrm{CDI}: \beta-\mathrm{CD}=1: 1$ ) under continuous stirring. The activation reaction was carried out at $293 \mathrm{~K}$ for $2 \mathrm{~h}$. $\beta$-CD-containing organosilane (II) was prepared by modification of APTES with aforementioned activated oligosaccharide $(I)$ at room temperature for $24 \mathrm{~h}$. Then, the obtained product was used for templated sol-gel synthesis of two CD-MCM-41 silicas. One of them, CD-MCM-41-1, was prepared by cocondensation of TEOS and $\boldsymbol{I} \boldsymbol{I}$ in the presence of activation reaction products. Another silica, CD-MCM-41-2, was synthesized by use of TEOS and purified $\beta$-CD-organosilane. Purification of $\beta$-CD-organosilane was realized in accordance with the following procedure. Dry acetone was added to the reaction mixture of $\beta$-CD-containing organosilane (II) to fall out substituted oligosaccharide [26,27], and the resultant precipitate was collected by filtration. After drying under vacuum, the yellow solid product was obtained. Finally, purified $\beta$-CD-organosilane was dissolved in dry DMF and co-condensed with TEOS in the presence of CTMABr. Ionic template was previously dissolved in water with stirring at room temperature, and $\mathrm{NH}_{4} \mathrm{OH}$ was added to provide the alkaline medium of the reaction. The reaction mixtures for both CD-MCM-41 silicas were agitated on magnetic stirrer for $2 \mathrm{~h}$. In order to complete the condensation process, the hydrothermal treatment in autoclave at $373 \mathrm{~K}$ for $24 \mathrm{~h}$ was carried out. The final molar composition of the reaction mixture for CD-MCM-41 silicas preparing was as follows: 0.05 TEOS : $0.001 \beta$-CD-organosilane : $0.007 \mathrm{CTMABr} \quad$ : $0.27 \mathrm{NH}_{4} \mathrm{OH}$ : $7.2 \mathrm{H}_{2} \mathrm{O}$. Both CD-MCM-41 materials were washed by small quantities of water and dried at ambient temperature. Then, the template was removed by triple solvent extraction in $\mathrm{HCl} / \mathrm{C}_{2} \mathrm{H}_{5} \mathrm{OH}$ solution at room temperature for $24 \mathrm{~h}$. After extraction, silicas were washed with distilled water until the negative test on halide anions with $\mathrm{AgNO}_{3}$. Obtained materials were dried in the air at $293 \mathrm{~K}$.

Characterization of MCM-41 silicas. The ordered mesoporosity of MCM-41-type silicas was confirmed by diffraction analysis at low angles $(2 \theta=1-10 \mathrm{grad})$ and transmission electron microscopy (TEM). Powder X-ray diffraction patterns (XRD) were measured on a DRON-4-02 diffractometer using $\mathrm{Cu} K_{\alpha}$ radiation $(\lambda=0.154178 \mathrm{~nm})$ and a nickel filter. TEM experiments were carried out on a JEM JEOL 1230 electron microscope operated at $100 \mathrm{kV}$. The 
transmission spectra were registered on a Thermo Nicollet NEXUS FT-IR spectrophotometer in the range from 4000 to $400 \mathrm{~cm}^{-1}$ for solid pellets of synthesized silicas. Porosity measurements were obtained with a Kelvin-1042 Sorptometer using low-temperature adsorption-desorption of nitrogen. Prior to measurements, all samples were outgased at $413 \mathrm{~K}$ for $20 \mathrm{~h}$. Specific surface area of MCM-41 silicas was determined using the BET method in the relative pressure range $\left(P / P_{0}\right)$ up to 0.30 . The pore size distributions were calculated by applying the NLDFT (equilibrium model). The total pore volume $\left(V_{\text {total }}\right)$ was obtained from the amount of nitrogen adsorbed at $P / P_{0}=0.99$.

The amount of surface aminopropyl groups was calculated by the difference in $\mathrm{pH}$ values (Ionometer I-160) of starting and equilibrium acid solutions with CD-MCM-41 (or $\mathrm{NH}_{2}-\mathrm{MCM}-41$ ) silica batch after $24 \mathrm{~h}$ contact [28]. The content of $\beta$-CD in CD-MCM-41 silicas was determined by acid hydrolysis of oligosaccharide up to glucose. The concentration of glucose after the reaction with potassium ferrocyanide was defined by spectrophotometry using a Specord M-40 equipment at $\lambda=420 \mathrm{~nm}[25,29]$.

Adsorption study. The adsorption behavior of benzene and phenol as a function of time and equilibrium concentration was studied on MCM-41, $\mathrm{NH}_{2}$-MCM-41, and ordered $\beta$-CDcontaining (CD-MCM-41-1 and CD-MCM-41-2) silicas.

The kinetic and adsorption equilibrium studies were realized by the multibatch method at room temperature $(291 \pm 1 \mathrm{~K})$. For kinetic experiments, air dried weighted amounts $(0.02 \mathrm{~g})$ of each silica were taken in air-tight vials, then $12 \mathrm{ml}$ of benzene aqueous solution $\left(0.45 \mathrm{~g} \cdot \mathrm{L}^{-1}\right)$ or $10 \mathrm{ml}$ of phenol solution $\left(0.64 \mathrm{~g} \cdot \mathrm{L}^{-1}\right)$ was rapidly added. The suspensions were stirred for predetermined time intervals, then filtered thought syringe filters (pores with $\mathrm{d}=0.2 \mu \mathrm{m}, \mathrm{PVDF}$ (Millipore)) to prevent the liberation of aromatic compound. The content of benzene or phenol in filtrates was determined by UV-spectrophotometry at $\lambda=254$ and $270 \mathrm{~nm}$, respectively.

For equilibrium adsorption experiments, aqueous solutions with benzene concentrations of $0.036-0.72 \mathrm{~g} \cdot \mathrm{L}^{-1}$ and phenol concentrations of $0.06-0.64 \mathrm{~g} \cdot \mathrm{L}^{-1}$ were used. Briefly, batches of air dried silica adsorbents $(0.01 \mathrm{~g}$ for benzene or $0.02 \mathrm{~g}$ for phenol) were taken in air-tight vials, and aqueous solutions of aromatics ( $12 \mathrm{ml}$ of benzene or $10 \mathrm{ml}$ of phenol) were added. After the absorption equilibrium was reached, the solutions were separated by syringe filter for determination of aromatic compounds concentration.

The contents of aromatics in solutions were calculated from the calibration curves prepared by plotting absorbance at $254 \mathrm{~nm}$ for benzene and $270 \mathrm{~nm}$ for phenol against certain concentrations of analytes in solutions in the range $0.01-0.45 \mathrm{~g} \cdot \mathrm{L}^{-1}$ or $0.06-0.64 \mathrm{~g} \cdot \mathrm{L}^{-1}$, respectively.

The amount of aromatics adsorbed on MCM-41-type silicas from aqueous solutions was evaluated as:

$$
a=\frac{\left(C_{o}-C_{f}\right) V}{m},
$$

where $a$-adsorption; $C_{o}$ - the initial concentration of aromatic compound in aqueous solution; $C_{f}-$ the concentration of aromatics in filtrate; $V$ - the volume of the aqueous solution of benzene (phenol); $m$ - the mass of adsorbent.

The experimental error (\%) in benzene/phenol concentration determination was calculated as follows:

$$
\frac{\Delta C}{C}=\frac{\Delta A+\Delta B \cdot D+B \cdot \Delta D}{C}
$$

where $\Delta C$ - the absolute error; $A, B$ and $\Delta A, \Delta B$ coefficients obtained from the calibration curve (an intercept and the slope) and their absolute errors at confident level 0.95 , respectively; $\Delta D$ was accepted as 0.005 (device error).

\section{RESULTS AND DISCUSSIONS}

The synthesis of nanoporous silicas with ordered structure is an active field of research. Mesoporous MCM-41 silicas offer a number of potential advantages as adsorbents, such as high surface area, large pore volume and regular channel type pore structure. In addition, the possibility of chemical modification of MCM-41type adsorbents by introducing specific functional groups into the silica matrix enhances their adsorption capacity. In this work, a new approach for $\beta$-CD-containing MCM-41 silica synthesis was demonstrated. A few mesoporous materials with ordered structure were prepared - MCM-41, $\mathrm{NH}_{2}-\mathrm{MCM}-41$, and two $\beta$-CD-MCM-41 silicas. Table 1 summarizes the structural parameters of all synthesized silicas.

To confirm that by-products of $\beta-\mathrm{CD}$ activation reaction could not affect the structure of the final silica, two types of CD-MCM-41 silicas 
were prepared by sol-gel synthesis. The chemical nature of surface and mesoporous structure of CD-MCM-41-1 and CD-MCM-41-2 silicas obtained in the presence of $\beta$-CD-silane with by-products and purified one, respectively, were compared.

Characterization of CD-MCM-41-1 and CD-MCM-41-2 prepared by co-condensation method was performed using FT-IR spectroscopy, chemical analysis, XRD, TEM, and lowtemperature adsorption-desorption of nitrogen.

The presence of organic component (cyclic oligosaccharide and/or aminopropyl functional groups) in MCM-41 silicas was proved by FT-IR spectroscopy and quantitative chemical analysis of silica materials. Fig. 1 shows the FT-IR spectra of the synthesized MCM-41 silicas. As can be seen from the spectrum of MCM-41 silica (Fig. $1 a$, Table 1), only absorption bands attributed to the valence and deformation vibrations of silica framework ( $\mathrm{Si}-\mathrm{O}-\mathrm{Si}$ and $\mathrm{Si}-\mathrm{OH})$ and remaining water molecules $(\mathrm{H}-\mathrm{O}-\mathrm{H}$ and $\mathrm{O}-\mathrm{H})$ are observed. Comparatively, in the FT-IR spectra of CD-MCM-41 silicas (Fig. $1 b, c$ ) the absorption bands at 2986, 2946 and 1450,1413, $1391 \mathrm{~cm}^{-1}$ corresponding to the valence and deformation vibrations of the $\mathrm{C}-\mathrm{H}$ bonds in the alkyl and glycosyl groups of incorporated compounds are registered. Moreover, the appearance of characteristic absorption bands at $1540 \mathrm{~cm}^{-1}$ can be attributed to the deformation vibrations of the $\mathrm{N}-\mathrm{H}$ bond in the secondary amino groups of $\beta$-CD-silane or/and grafted functional groups. Absorption bands belonging to the deformation vibrations of the $\mathrm{N}-\mathrm{H}$ bond in the residual primary amino groups $\left(1560-1640 \mathrm{~cm}^{-1}\right)$ as well as the valence vibrations of the $\mathrm{C}=\mathrm{O}$ bond in the amide linkage (near by $1700 \mathrm{~cm}^{-1}$ ) [30] of synthesized silicas are not registered because of their overlapping with strong signal attributed to the deformation vibrations of the $\mathrm{O}-\mathrm{H}$ bond in the adsorbed water molecules. Based on the results of FT-IR spectroscopy, it can be assumed the incorporation of $\beta$-CD-silane in the structure of silicas synthesized by templated sol-gel method. The appearance of aminopropyl groups in CD-MCM-41 points to the partial hydrolysis of amide bonds under hydrothermal treatment of $\beta$-CD-containing silicas in the medium of ammonium. An increase of oligosaccharide amount in CD-MCM-41-1 silica in comparison with CD-MCM-41-2 could be explained by the catalytic influence of resulting imidazole on the hydrolysis reaction of sol-gel process (Table 1).

Table 1. Structural parameters of synthesized MCM-41 silicas

\begin{tabular}{|c|c|c|c|c|c|c|c|c|c|c|}
\hline \multirow{3}{*}{ Silica } & \multirow{3}{*}{$\begin{array}{c}d_{100}, \\
\mathbf{n m}\end{array}$} & \multirow{3}{*}{$\underset{\mathbf{n m}}{a,}$} & \multirow{3}{*}{$\begin{array}{c}S_{B E T}, \\
\mathrm{~m}^{2} \cdot \mathrm{g}^{-1}\end{array}$} & \multirow{3}{*}{$\begin{array}{c}V_{\text {total }} \\
\mathrm{cm}^{3} \cdot \mathrm{g}^{-1}\end{array}$} & \multirow{3}{*}{\multicolumn{2}{|c|}{$\begin{array}{c}D_{D F T}, \\
\mathbf{n m}\end{array}$}} & \multicolumn{4}{|c|}{ Group loading } \\
\hline & & & & & & & \multicolumn{2}{|c|}{$\left[-\left(\mathrm{CH}_{2}\right)_{3} \mathrm{NH}_{2}\right]}$, & \multicolumn{2}{|c|}{$[\beta-C D]$} \\
\hline & & & & & & & 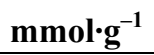 & $\mu \mathrm{mol} \cdot \mathrm{m}^{-2}$ & ${\mathrm{mmol} \cdot \mathrm{g}^{-1}}$ & $\mu \mathrm{mol} \cdot \mathrm{m}^{-2}$ \\
\hline MCM-41 & 4.17 & 4.82 & 995 & 0.75 & 3.7 & 5.1 & - & - & - & - \\
\hline $\mathrm{NH}_{2}-\mathrm{MCM}-41$ & 4.02 & 4.64 & 523 & 0.86 & 3.7 & 5.1 & 0.44 & 0.84 & - & - \\
\hline CD-MCM-41-1 & 4.11 & 4.75 & 812 & 1.06 & 3.9 & 5.1 & 0.05 & 0.06 & 0.018 & 0.022 \\
\hline CD-MCM-41-2 & 4.11 & 4.75 & 802 & 1.38 & 3.9 & 5.2 & 0.04 & 0.05 & 0.010 & 0.012 \\
\hline
\end{tabular}

Hexagonally ordered pore structure of obtained silicas was confirmed by XRD and TEM analyses. As could be clearly seen from the Fig. 2, the unidimensional cylindrical pores of CD-MCM-41 silicas are arranged in a honeycomb structure. Also, XRD patterns of synthesized CD-MCM-41 silicas are shown in Fig. 2 (inset). The presence of diffraction peaks at $2 \theta=2.15$ are attributed to the (100) reticular planes in CD-MCM-41-1 and CD-MCM-41-2 silicas. Moreover, distinct reflexes on the XRD patterns between 3.5 and 5 grad could be indexed to the (110) and (200) reticular planes of hexagonally packed pores and confirm the formation of two-dimensionally periodic hexagonal lattice, which is characteristic for MCM-41 materials. Structural parameters (interplanar distance $d$ and unit cell parameter $a$ ) calculated from XRD analysis for all silicas are summarized in Table 1. Besides, the same values of $d$ and $a$ diffraction parameters of CD-containing silicas denote that the presence of activation reaction products in CD-MCM-41-1 sol-gel synthesis has no noticeable effect on forming of ordered hexagonal network of pores.

Fig. 3 displays isotherms of nitrogen adsorption-desorption and pore size distributions 
for CD-MCM-41-1 and CD-MCM-41-2 silicas. Nitrogen adsorption at low relative pressures $P / P_{0}<0.3$ for CD-MCM-41 silicas is attributed to the monolayer adsorption, following multilayer adsorption on the walls of mesopores. The distinct step on the isotherm at $P / P_{0} \sim 0.35$ indicates a uniformly porous surface. The pore size distribution plots clearly demonstrate that uniform pores are prevailing in CD-MCM-41 materials causing the high peak centered at $3.9 \mathrm{~nm}$. The appearance of larger pores (slight peak above $5 \mathrm{~nm}$ ) can be explained by partial degradation of the walls between individual channels of pores in the process of hydrothermal treatment carried out at $373 \mathrm{~K}$ in the medium of ammonia. Also, the
CD-MCM-41-1 and CD-MCM-41-2 isotherms similarity confirms that by-products of $\beta-C D$ activation reaction do not affect the pore structure of the resulting silica. The values of BET specific surface area for CD-MCM-41 silicas calculated from linear region of isotherms are more than $800 \mathrm{~m}^{2} \cdot \mathrm{g}^{-1}$. Early, it was demonstrated the incorporation of cyclodextrin into mesostructured silica by templated synthesis with 1,3,5-trimethylbenzene as a pore-expanding agent [31]. It is worth noting that here $\beta$-CD-containing silicas with high surface areas, pore volume, and large-scale ordering were managed to get by sol-gel method without any pore-expanding agent.

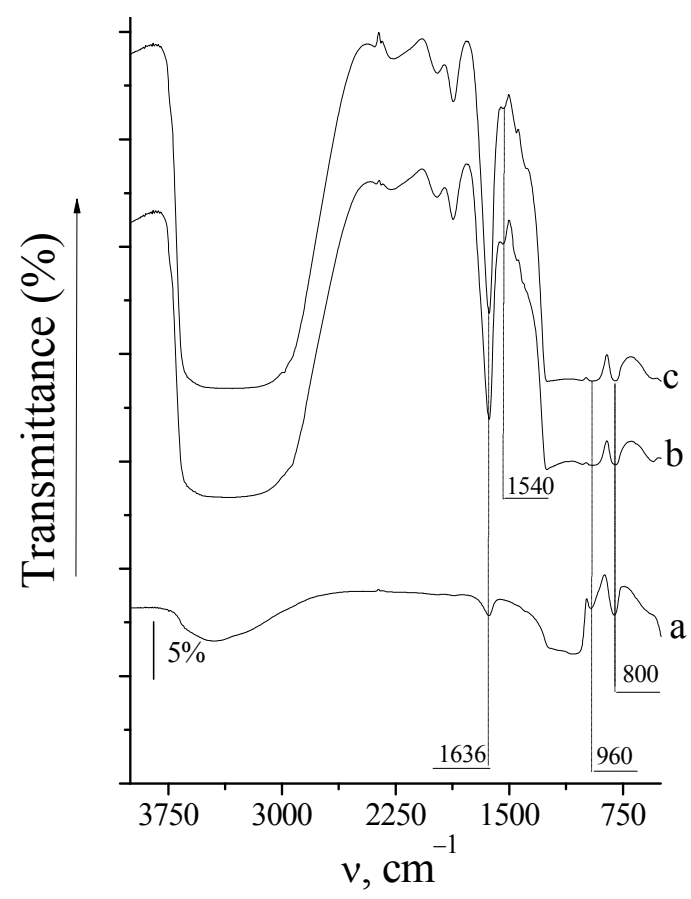

Fig. 1. IR spectra of MCM-41 (a), CD-MCM-41-1 (b), and CD-MCM-41-2 (c) silicas
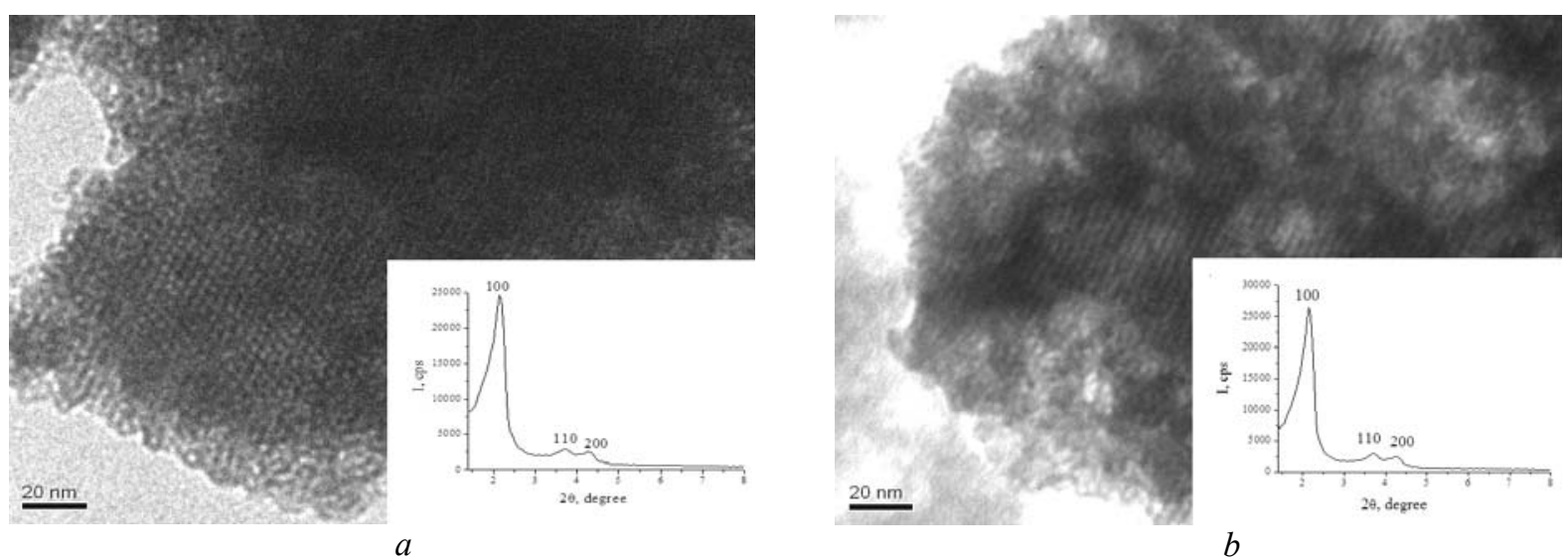

Fig. 2. TEM images and XRD patterns (inset) of CD-MCM-41-1(a) and CD-MCM-41-2 (b) silicas 


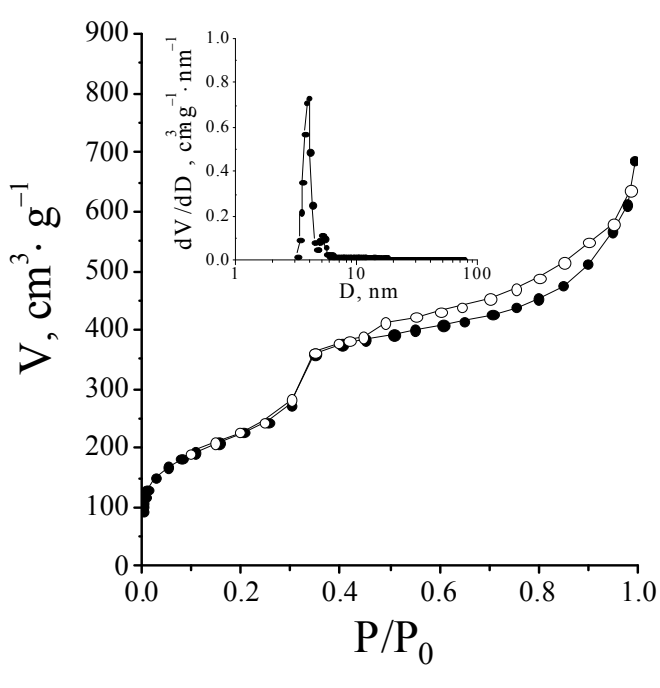

$a$

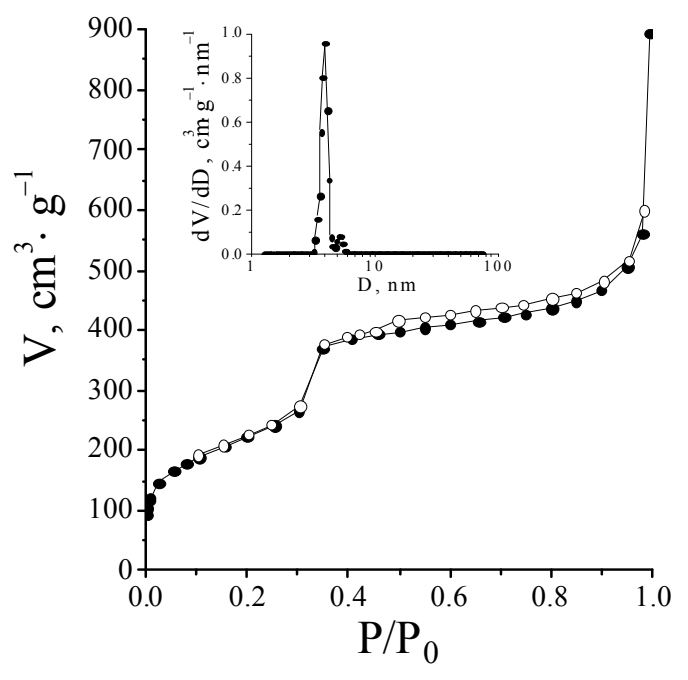

$b$

Fig. 3. Nitrogen adsorption-desorption isotherms and NLDFT pore diameter of CD-MCM-41-1 (a) and CD-MCM-41-2 (b). Solid symbols denote adsorption, and open ones denote desorption

Incorporation of cyclic oligosaccharide into solid supports like MCM-41 silicas makes possible an efficient removing of aromatic pollutants from aqueous solutions by means of supramolecular structures formation. Here, adsorption behavior of functionalized MCM-41 silicas was studied by removing of benzene and phenol from aqueous solutions.

Adsorption kinetic experiments were carried out to evaluate a period which should be sufficient to reach adsorption equilibrium. Fig. 4 represents the kinetic curves for benzene uptake from aqueous solutions with MCM-41,

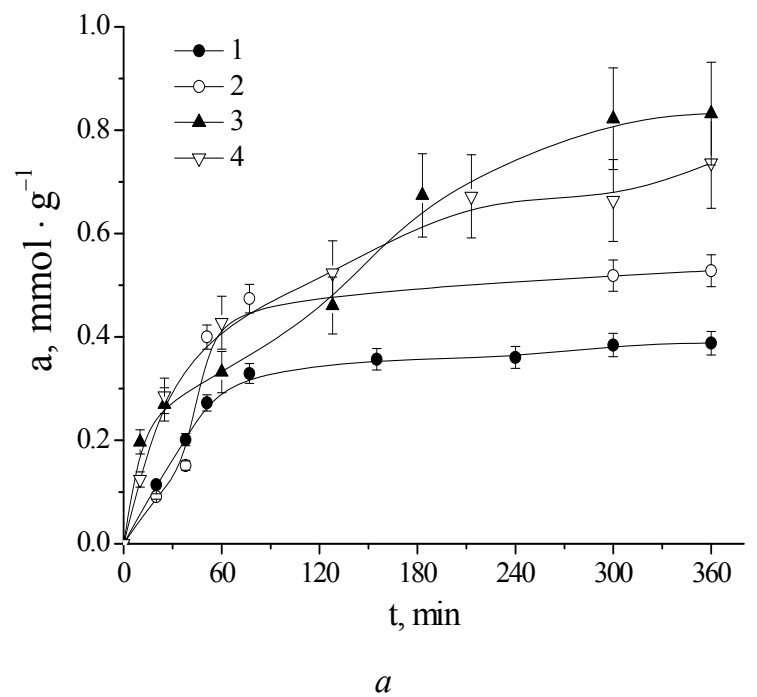

$\mathrm{NH}_{2}$-MCM-41, CD-MCM-41-1, and CD-MCM-41-2 silicas. The adsorption of benzene on MCM-41 and $\mathrm{NH}_{2}-\mathrm{MCM}-41$ silicas is characterized by rapid uptake of aromatic molecules within the first hour until it slows down and becomes constant at $5 \mathrm{~h}$. For CD-MCM-41 silicas, adsorptive uptake of benzene increases slowly and becomes constant in about $6 \mathrm{~h}$. The adsorption kinetic curves of phenol on CD-MCM-41 silicas followed an ascending trend with time in the region up to one hour (Fig. 5).

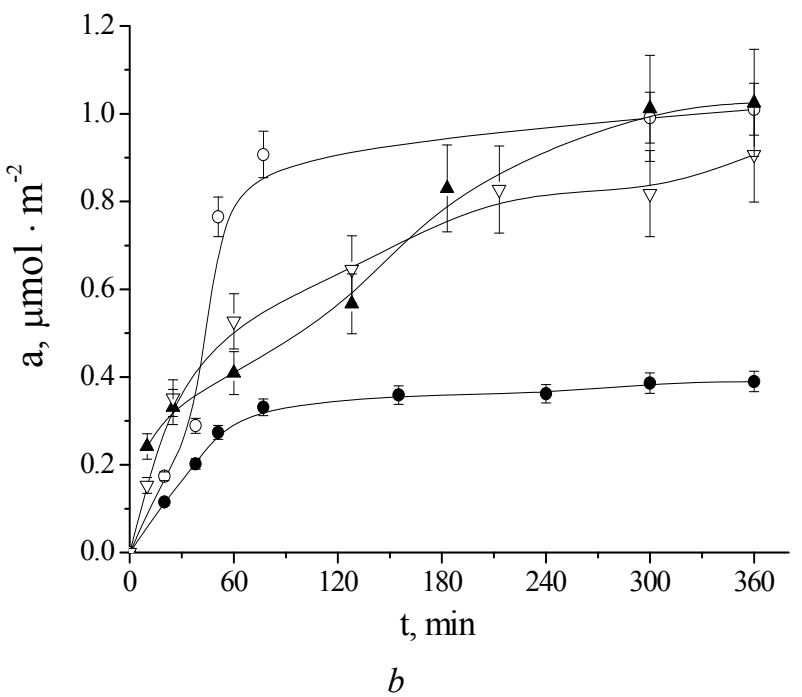

Fig. 4. Kinetic curves of benzene adsorption on MCM-41 (1), $\mathrm{NH}_{2}-\mathrm{MCM}-41$ (2), CD-MCM-41-1 (3), and CD-MCM-41-2 (4) silicas per $\mathrm{g}(a)$ or per $\mathrm{m}^{2}(b)$ of materials 

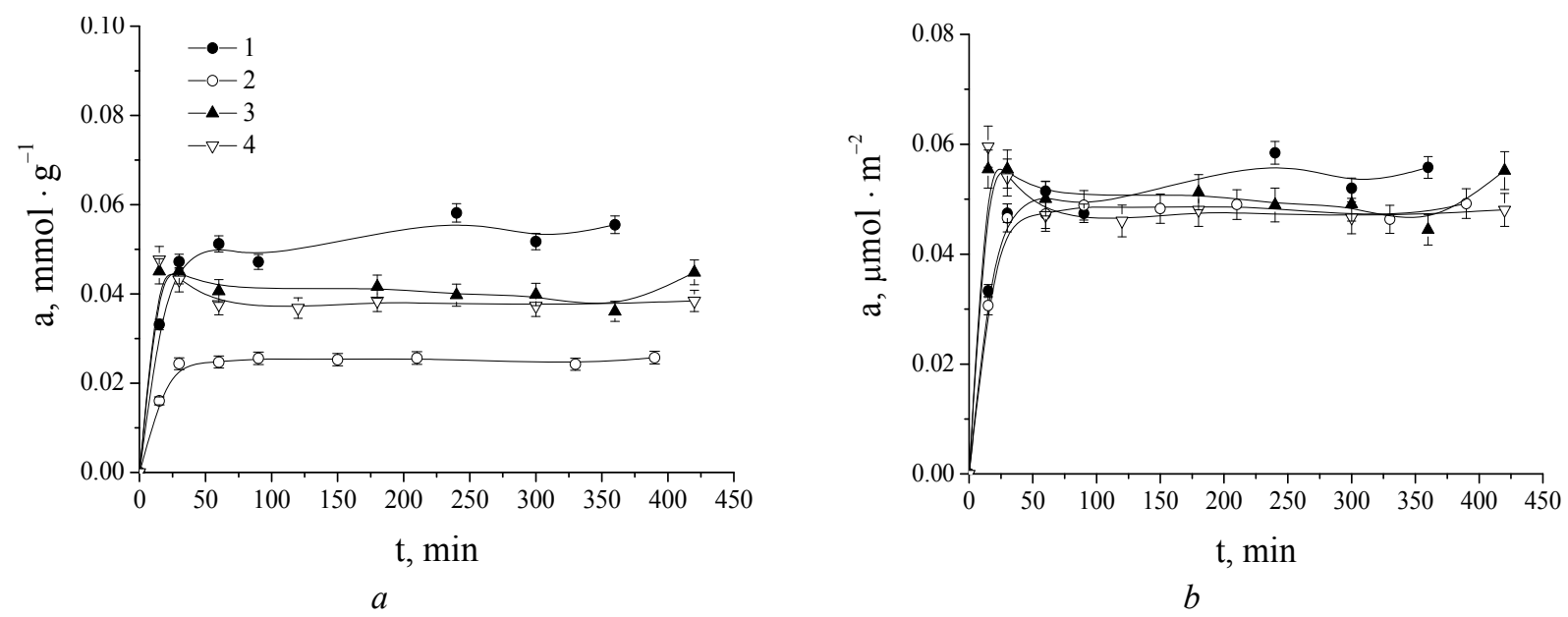

Fig. 5. Kinetic curves of phenol adsorption on MCM-41 (1), $\mathrm{NH}_{2}$-MCM-41 (2), CD-MCM-41-1 (3), and CD-MCM-41-2 (4) silicas per $\mathrm{g}(a)$ or per $\mathrm{m}^{2}(b)$ of materials

It was shown that $\beta-\mathrm{CD}$ and aromatic compounds could form "host-guest" inclusion complexes in aqueous solutions. The formation of " $\beta-C D$ - aromatic compound" complexes is spontaneous and thermodynamically profitable exothermal process $[32,33]$. The equilibrium adsorption study was used to evaluate the role of cyclic oligosaccharide fragments as specific adsorption sites of ordered CD-MCM-41 silicas. The adsorption isotherms of benzene from aqueous solutions as quantity of benzene adsorbed per unit weight of silica or per unit of adsorbent surface are given in Fig. $6 a$ and $6 b$, respectively. The adsorption of benzene on silicas based on interactions of the aromatic ring of $\pi$-electrons with the surface silanol groups is well known [34]. It can be seen that adsorption isotherms of benzene on MCM-41 and $\mathrm{NH}_{2}-\mathrm{MCM}-41$ silicas have concave shape in the region of small equilibrium concentrations of adsorbate as a result of weak affinity of non-polar aromatic rings to polar silanol groups, but then followed a sharp increase of aromatic uptake. Obviously, it could be explained by the reorientation of benzene molecules owing to increase in its concentration in the solutions. As follows, the more benzene is already adsorbed, the easier it is for additional amounts to become fixed as a result of hydrophobic interaction [35]. The character of benzene adsorption on the surface of CD-MCM-41 silicas is considerably different. In the region of small equilibrium concentrations, the higher adsorption of benzene compared to MCM-41 and $\mathrm{NH}_{2}-\mathrm{MCM}-41$ silicas is observed. Apparently, the uptake of benzene molecules is caused by non-specific binding interaction with silica matrix as well as selective binding sites within its structure.

It has been shown that typical adsorption capacities for carbon and silica adsorbents in liquid phase under different conditions are in the range of $12-230 \mathrm{mg} \cdot \mathrm{g}^{-1}$ for benzene $[36,37]$. Therefore, prepared CD-MCM-41 silicas demonstrate adsorption level performance of known samples (up to $87 \mathrm{mg} \cdot \mathrm{g}^{-1}$ in studied concentration diapason), and could be very promising for the treatment of aqueous solutions with low benzene concentration.

The adsorption equilibrium data of synthesized silicas for phenol are shown in Fig. 7. It can be seen that phenol adsorption performance is weak in comparison with benzene one, which is consistent with the literature [36,37]. Despite low adsorbed amount of phenol, different adsorption behavior of MCM-41, $\mathrm{NH}_{2}-\mathrm{MCM}-41$ and CD-MCM-41 silicas are clearly seen (Fig. 7).

The significant uptake of phenol on CD-MCM-41 silicas in comparison with MCM-41 and $\mathrm{NH}_{2}-\mathrm{MCM}-41$ is observed at equilibrium concentration around $3 \mathrm{mmol} \cdot \mathrm{L}^{-1}$. Here, the amount of phenol removed from aqueous media is almost equal to $\beta-\mathrm{CD}$ content into CD-MCM-41-1 and CD-MCM-41-2 silicas, confirming the chemical incorporation of $\beta$-cyclodextrin and its availability for specific hydrophobic interactions with phenol molecules $(1: 1$ inclusion complex formation). In general, adsorption of phenol on CD-MCM-41 silica involves hydrophobic interactions of phenol molecules with surface $\beta-C D$ moieties as well as interactions of the aromatic ring of $\pi$-electrons with the surface silanol groups and 
acid-base interactions of phenol hydroxyl groups with surface amine groups.

A close inspection of benzene/phenol adsorption isotherms on MCM-41, $\mathrm{NH}_{2}-\mathrm{MCM}-41$, CD-MCM-41-1, and CD-MCM-41-2 silicas reveals that the uptake of aromatic molecules from aqueous solutions is efficient for materials with incorporated oligosaccharide molecules in the equilibrium concentration up to $4-5 \mathrm{mmol} \cdot \mathrm{L}^{-1}$. In comparison, at comparatively high concentrations

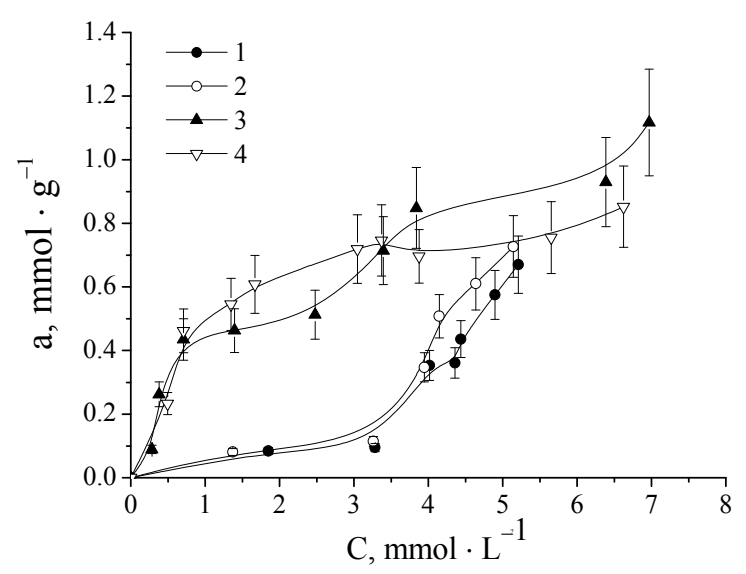

$a$ adsorption effectiveness of all studied silicas is almost the same. This signifies that synthesized $\beta$-CD-MCM-41 silica can act as effective adsorbents for trace amounts of aromatic compounds in water systems. Moreover, the higher adsorption performance of $\beta$-CD-MCM-41 silicas towards benzene and their adsorptive affinity to phenol can be useful in the separation of aromatic compounds.

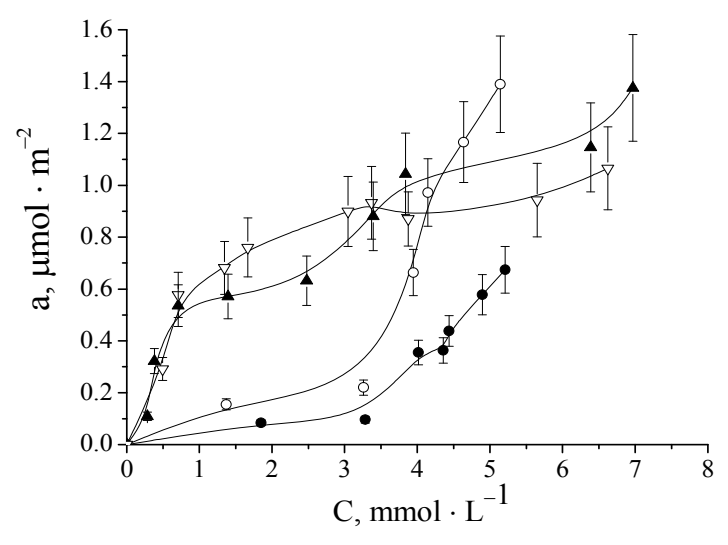

$b$

Fig. 6. Benzene adsorption isotherms on MCM-41 (1), $\mathrm{NH}_{2}-\mathrm{MCM}-41$ (2), CD-MCM-41-1 (3), and CD-MCM-41-2 (4) silicas per $\mathrm{g}(a)$ or per $\mathrm{m}^{2}(b)$ of materials

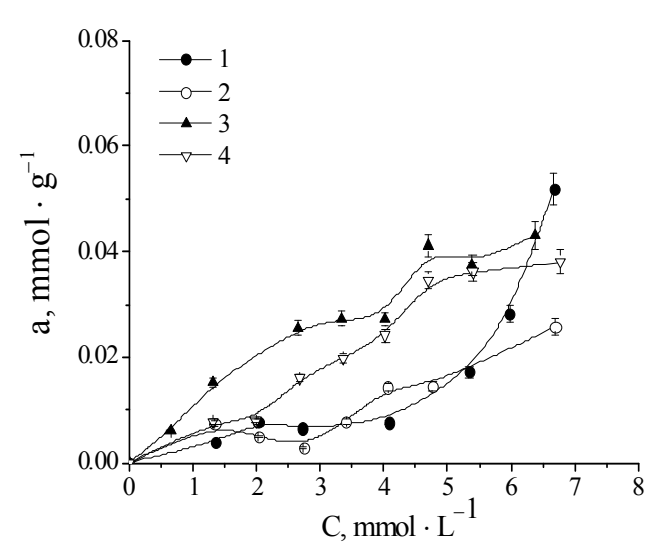

$a$

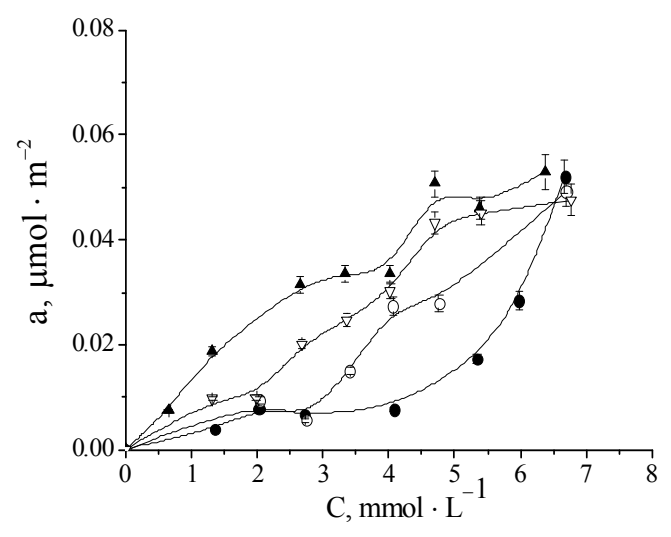

b

Fig. 7. Phenol adsorption isotherms on MCM-41 (1), $\mathrm{NH}_{2}-\mathrm{MCM}-41$ (2), CD-MCM-41-1 (3), and CD-MCM-41-2 (4) silicas per $\mathrm{g}(a)$ or per $\mathrm{m}^{2}(b)$ of materials

\section{CONCLUSIONS}

In this study, we report on the synthesis and characterization of $\beta$-cyclodextrin-MCM-41 silica obtained with $\beta$-cyclodextrin-containing silane in the presence of ionic template (cetyltrimethyl- ammonium bromide). $\beta$-Cyclodextrin-silane was prepared by modification of (3-aminopropyl)triethoxysilane with oligosaccharide activated by N,N'-carbonyldiimidazole. On the basis of XRD, TEM, low-temperature adsorption-desorption of nitrogen, FT-IR spectroscopy and quantitative 
chemical analysis, it has been shown that obtained silica is a well-ordered mesoporous material with high surface area (about $800 \mathrm{~m}^{2} \cdot \mathrm{g}^{-1}$ ) and sufficient oligosaccharide group loading (up to $0.022 \mu \mathrm{mol} \cdot \mathrm{m}^{-2}$ ). Also, the adsorption of aromatic compounds (benzene and phenol) from aqueous solutions on the surface of $\beta$-cyclodextrin-MCM-41 silica was studied as a function of time and equilibrium concentration. The improved adsorption properties of synthesized material were observed and compared with MCM-41 and $\mathrm{NH}_{2}-\mathrm{MCM}-41$ silicas. The proposed synthesis approach may be applicable for obtaining of ordered $\beta$-CD-containing functional materials with high affinity to aromatic compounds of suitable geometry for water purification.

\title{
ק-Циклодекстрин-МСМ-41 кремнезем як перспективний адсорбент для вилучення слідових кількостей ароматичних сполук 3 води
}

\author{
І.М. Трофимчук, Н.В. Роїк, Л.О. Бєлякова
}

Інститут хімії поверхні ім. О.О. Чуйка Національної академії наук України вул. Генерала Наумова, 17, Київ, 03164, Украӥна, trofymchuk_iryna@ukr.net

\begin{abstract}
У изьому дослідженні здійснено золь-гель синтез $\beta$-цииклодекстрин-МСМ-41 кремнезему з використанням $\beta$-циклодекстринвмісного силану і тетраетилортосилікату (як джерел кремнезему) в присутності йонного темплату (цетилтриметиламоній броміду). $\beta$-Циклодекстринвмісний силан було одержано шляхом модифікування (3-амінопропіл)триетоксисилану олігосахаридом, який активували у присутності $N, N^{\prime}$-карбонілдиімідазолу. Успішне введення $\beta$-изилодекстринових фрагментів у кремнезем було підтверджено за допомогою Фур'є-ІЧ спектроскопї та кількісного хімічного аналізу. Одержаний в-цииклодекстрин-МСМ-41 кремнезем охарактеризовано методами рентгенівської дифракції, трансмісійної електронної мікроскопї та низькотемпературної адсорбиії-десорбиії азоту. Вивчено адсорбиію бензену та фенолу з водних розчинів на $\beta$-ииклодекстрин-МСM-41 кремнеземі в залежності від тривалості контакту та рівноважної концентрачії адсорбтиву. Продемонстрована більща специфічність адсорбиї ароматичних сполук на $\beta$-циклодекстрин-МСМ-41кремнеземі у порівнянні з МСМ-41.
\end{abstract}

Ключові слова: МСM-41, $\beta$-ичиклодекстрин, золь-гель синтез, адсорбиія, ароматичні сполуки

\section{ק-Циклодекстрин-МСМ-41 кремнезем как перспективный адсорбент для извлечения следовых количеств ароматических соединений из воды}

\author{
И.Н. Трофимчук, Н.В. Роик, Л.А. Белякова
}

Институт химии поверхности им. А.А. Чуйко Наџиональной академии наук Украиньл ул. Генерала Наумова, 17, Киев, 03164, Украина, trofymchuk_iryna@ukr.net

В этом исследовании осуществлен золь-гель синтез $\beta$-циилодекстрин-МСМ-41 кремнезема с использованием $\beta$-ииклодекстринсодержащего силана и тетраэтилортосиликата (в качестве источников кремнезема) в присутствии ионного темплата (цетилтриметиламмоний бромида). $\beta$-цииллодекттринсодержащий силан был получен путем модифицирования (3-аминопропил)триэтоксисилана олигосахаридом, активированным N,N'-карбонилдиимидазолом. Успешное введение $\beta$-циклодекстриновых фрагментов в кремнезем было подтверждено с помощью Фурье-ИК спектроскопии и количественного химического анализа. Полученный $\beta$-ичклодекстрин-МСМ-41 кремнезем охарактеризован методами рентгеновской дифракиии, трансмиссионной электронной микроскопии и низкотемпературной адсорбиии-десорбции азота. Изучена адсорбчия бензола и фенола из водных растворов на $\beta$-ииклодекстрин-МСМ-41 кремнеземе в зависимости от длительности контакта и равновесной концентрачии адсорбтива. Продемонстрирована более высокая специфичность адсорбции ароматических соединений на $\beta$-ииклодекстрин-МСМ-41 кремнеземе по сравнению с МСМ-41.

Ключевые слова: МСM-41, $\beta$-цฺиклодекстрин, золь-гель синтез, адсорбция, ароматические соединения 


\section{REFERENCES}

1. Busca G., Berardinelli S., Resini C., Arrighi L. Technologies for the removal of phenol from fluid streams: A short review of recent developments. J. Hazard. Mater. 2008. 160(2-3): 265.

2. Kuykendall J.R. Benzene. Encyclopedia of Ecology. Reference Module in Earth Systems and Environmental Sciences. (Amsterdam: Elsevier, 2008).

3. Stewart A.J., Stewart R.F. Phenols. Encyclopedia of Ecology. Reference Module in Earth Systems and Environmental Sciences. (Amsterdam: Elsevier, 2008).

4. Hindarso H., Ismadij S., Wicaksana F., Indraswati N. Adsorption of benzene and toluene from aqueous solution onto granular activated carbon. J. Chem. Eng. Data. 2001. 46(4):788.

5. Roostaei N., Tezel F.H. Removal of phenol from aqueous solutions by adsorption. J. Environ. Manage. 2004. 70(2): 157.

6. Dabrowski A., Podkościelny P., Hubicki Z., Barczak M. Adsorption of phenolic compounds by activated carbon - a critical review. Chemosphere. 2005. 58(8): 1049.

7. Koh S.M., Dixon J.B. Preparation and application of organo-minerals as sorbents of phenol, benzene and toluene. Appl. Clay Sci. 2001. 18(3-4): 111.

8. Kuleyin A. Removal of phenol and 4-chlorophenol by surfactant-modified natural zeolite. J. Hazard. Mater. 2007. 144(1-2): 307.

9. Fu J., He Q., Wang R., Liu B., Hu B. Comparative study of phenol compounds adsorption on mesoporous sieves with different degrees of modification. Colloids Surf., A. 2011. 375(1-3): 136.

10. Wang X., Lu M., Wang H., Pei Y., Rao H., Du X. Three-dimensional graphene aerogels-mesoporous silica frameworks for superior adsorption capability of phenols. Sep. Purif. Technol. 2015. 153 : 7.

11. Li A., Zhang Q., Wu H., Zhai Z., Liu F., Fei Z., Long Ch., Zhu Z, Chen J. A new amine-modified hypercrosslinked polymeric adsorbent for removing phenolic compounds from aqueous solutions. Adsorpt. Sci. Technol. 2004. 22: 807.

12. Lin S.H., Juang R.S. Adsorption of phenol and its derivatives from water using synthetic resins and low-cost natural adsorbents: A review. J. Environ. Manage. 2009. 90(3): 1336.

13. Choi J.W., Chung S.G., Baek K.Y., Cho K.Y., Hong S.W., Kim D.J., Lee S.H. Removal of benzene using the characteristics of block copolymers for encapsulation. Water Air Soil Pollut. 2012. 223(2): 609.

14. Laros S., Meniai A.H. The use of sawdust as by product adsorbent of organic pollutant from wastewater adsorption of phenol. Energy Procedia. 2012. 18: 905.

15. Abdel-Ghani N.T., El-Ghaghaby G.A., Helal F.S. Preparation, characterization and phenol adsorption capacity of activated carbons from African beech wood sawdust. Global J. Environ. Sci. Manage. 2016. 2(3): 209.

16. Banerjee A., Ghoshal A.K. Biodegradation of phenol by calcium-alginate immobilized Bacillus cereus in a packed bed reactor and determination of the mass transfer correlation. J. Environ. Chem. Eng. 2016. 4(2):1523.

17. Wu C., Lui X., Wei D., Fan I., Wang L. Photosonochemical degradation of phenol in water. Water Res. 2001. 35(16): 3927.

18. Jandacek R.J., Bohne R.L. The removal of organic substances from water with nonvolatile edible solvents. $J$. Am. Oil Chem. Soc. 1980. 57(9): 705A.

19. Weschayanwiwat P., Kunanupap O., Scamehorn J.E. Benzene removal from waste water using aqueous surfactant two-phase extraction with cationic and anionic surfactant mixtures. Chemosphere. 2008. 72(7): 1043.

20. Wu J., Rudy K., Spark J. Oxidation of aqueous phenol by ozone or peroxidase. Adv. Environ. Res. 2000. 4(4): 339.

21. Mixa A., Staudt C. Membrane-based separation of phenol/water mixtures using ionically and covalently crosslinked ethylene-methacrylic acid copolymers. Int. J. Chem. Eng. 2008. 2008: 12.

22. Lefebvre E., Legube B. Coagulation-flocculation by ferric chloride of some organic compounds in aqueous solution. Water Res. 1993. 27: 433.

23. Del Valle E.M. Cyclodextrins and their uses: a review. Process. Biochem. 2004. 39(9): 1033.

24. Roik N.V., Belyakova L.A. Sol-gel synthesis of MCM-41 silicas and selective vapor-phase modification of their surface. J. Solid State Chem. 2013. 207: 194.

25. Roik N.V., Belyakova L.A. Interaction of supramolecular centers of silica surface with aromatic amino acids. J. Colloid Interf. Sci. 2011. 362(1): 172.

26. Hsieh M.L., Li G.Y., Chau L.K., Hon Ys. Single-step approach to $\beta$-cyclodextrin-bonded silica as monolithic stationary phases for CEC. J. Sep. Sci. 2008. 31(10): 1819.

27. Eguchi M., Du Y.Z., Taira S., Kodaka M. Functional nanoparticles based on $\beta$-cyclodextrin: preparation and properties. Nanobiothechnology. 2005. 1: 165. 
28. Belyakova L.A., Vlasova N.N., Golovkova L.P., Varvarin A.M., Lyashenko D.Yu., Svezhentsova A.A., Stukalina N.G., Chuiko A.A. Role of surface nature of functional silicas in adsorption of monocarboxylic and bile acids. J. Colloid Interf. Sci. 2003. 258(1): 1.

29. Korenman I.M. Photometric analysis. Methods of determination of organic compounds. (Moscow: Khimia, 1970). [in Russian].

30. Nakanishi K. Infrared absorption spectroscopy, practical. (San Francisco: Holden-Day, 1962).

31. Huq R., Mercier L., Kooyman P.J. Incorporation of cyclodextrin into mesostructured silica. Chem. Mater. 2001. 13(12): 4512.

32. Lewis E.A., Hansen L.D. Thermodynamics of binding of guest molecules to $\alpha$ - and $\beta$-cyclodextrins. J. Chem. Soc., Perkin Trans. 1973. 2: 2081.

33. Trofymchuk I.M., Belyakova L.A., Grebenyuk A.G. Study of complex formation between $\beta$-cyclodextrin and benzene. J. Incl. Phenom. Macro. 2011. 69(3): 371.

34. Gregg S.J., Sing K.S.W. Adsorption, surface area and porosity. (London: Academic press, 1982).

35. Giles C.H., MacEwan T.H., Nahwa S.N., Smith D. 786. Studies in adsorption. Part XI. A system of classification of solution adsorption isotherms, and its use in diagnosis of adsorption mechanisms and in measurement of specific surface areas of solids. J. Chem. Soc. 1960. 69: 3973.

36. Asenjo N.G., Alvarez P., Granda M., Blanco C., Santamaria R., Mendez R. High performance activated carbon for benzene/toluene adsorption from industrial wastewater. J. Hazard. Mater. 2011. 192(3): 1525.

37. Ghiaci M., Abbaspur A., Kia R., Seyedeyn-Azad F. Equilibrium isotherm studies for the sorption of benzene, toluene, and phenol onto organo-zeolites and as-synthesized MCM-41. Sep. Purif. Technol. 2004. 40(3): 217.

38. Matias T., Marques J., Quina M.J., Gando-Fereira L., Valente A.J.M., Portugal A., Duraes L. Silica-based aerogels as adsorbent for phenol-derivative compounds. Colloid Surf., A. 2015. 480: 260. 